\title{
World Geo-graphic Atlas
}

Die Württembergische Landesbibliothek hat im Oktober 2018 einen ganz besonderen Atlas erworben: Den „World Geo-graphic Atlas" aus dem Jahr 1953 - maßgeblich gestaltet von Herbert Bayer. Herbert Bayer (1900-1985) stammte ursprünglich aus Österreich und war Fotograf, Grafikdesigner, Typograf, Ausstellungsarchitekt, Maler und Lehrer am Bauhaus in Dessau. Dort hatte er schon von 1921 bis 1925 studiert, bevor er gleich im Anschluss 1925 als Leiter der neu eingerichteten Werkstatt für

\section{Druck und}

Reklame ans

Bauhaus be-

rufen wurde.

1928 mach-

te er sich

selbstständig.

In der Zeit des

Nationalsozia-

lismus gestal-

tete Bayer

NS-Propagan-

da-Ausstel-

lungen mit,

während 1937

auch Werke

von inm in

der Ausstel-

lung „Entartete

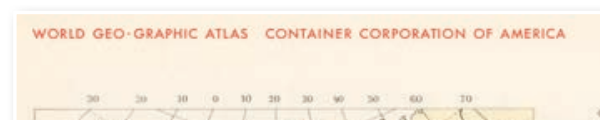

better than detailed tables difficult to remember." (Preface, S. 4). Die Karten stammten von anderen Verlagen und Herstellern, so etwa vom Verlag Rand McNally und vom Istituto Geografico de Agostini in Novara.

Der 1953 von der "Container Corporation" herausgegebene Atlas sollte auch höhere Ziele verfolgen, er sollte dazu beitragen "to know more about the geography and the conditions of life of our neighbors in the world so that we may have a better un-

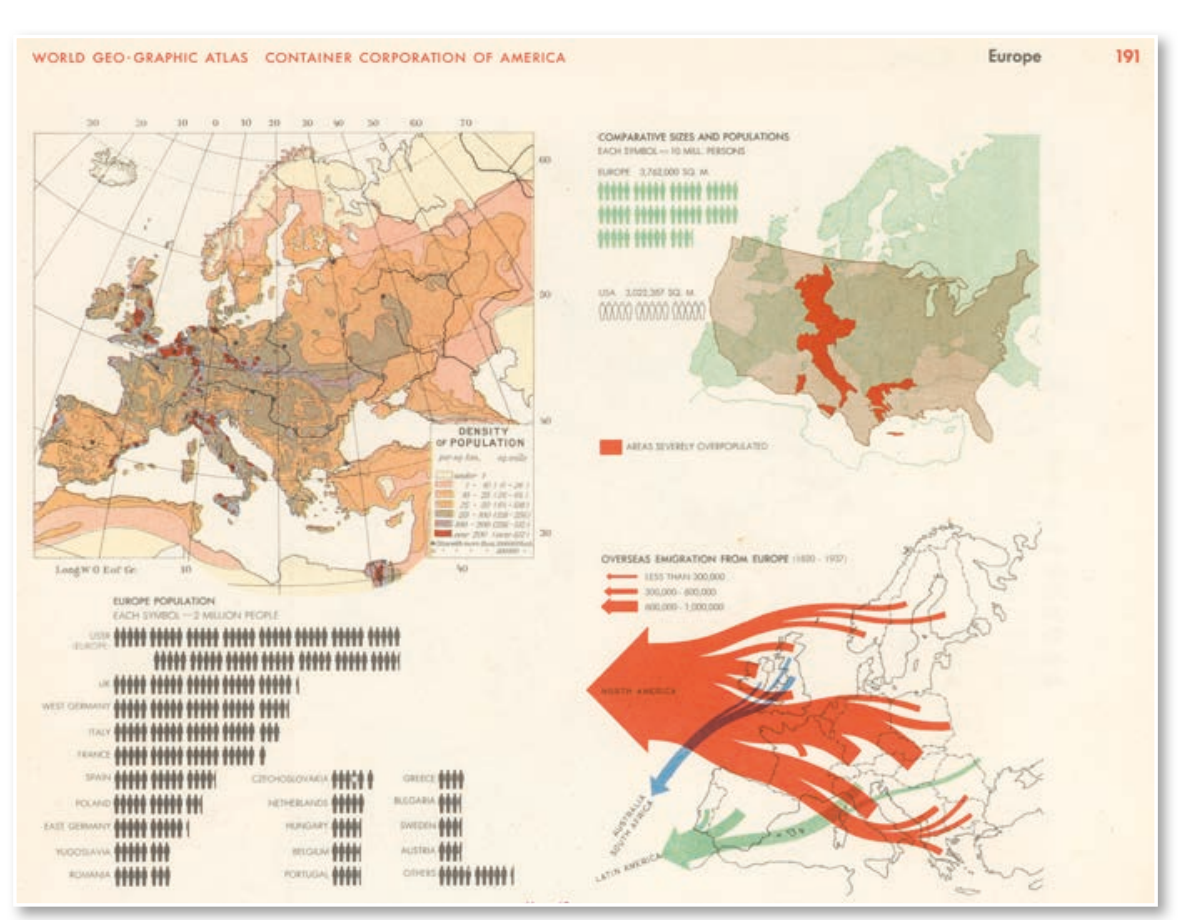

Bevölkerung und Bevölkerungsentwicklung in Europa (S. 191)

derstanding of other peoples and nations".

Die Firma legte insgesamt viel Wert auf Design und Layout ihrer Produkte und so sollte ein Produkt wie der Atlas nicht nur erzieherisch, sondern auch geschmacksbildend wirken. Der Atlas selbst umfasst 368 Seiten mit Kunst" zu sehen waren. 1938 emigrierte Bayer in die USA, wo er von 1946 bis 1965 bei der Container Corporation of America (CCA), einem 1926 gegründeten Logistik-Unternehmen, tätig war. Für diese Firma gestaltete er auch den World Geo-graphic Atlas, der als Privatdruck der Firma erschien. Der Begriff "geographic" wurde im Titel bewusst mit Bindestrich geschrieben, da der Atlas nicht nur eine Sammlung von Karten war, sondern auch zahlreiche graphische Illustrationen enthielt. Die zusätzlichen geographischen Informationen waren 120 ganzseitigen Karten. Dazu kommen ca. 1.200 Diagramme und Graphiken. Anfänglich wurden 150 Kopien gedruckt, die umsonst an Schulen und Bibliotheken verteilt wurden. Einem Rezensenten galt der Atlas 1955 als "the handsomest and best atlas ever published in America".

Zahlreiche Grafiken Bayers aus dem Atlas wurden in "Goldmanns große[n] Weltatlas" übernommen, der 1955 in München erschien.

Hans-Christian Pust

„designed in an abbreviated, simplified style with extensive use of the pictorial medium. The design of graphic symbols for all statistical charts confined the information to the essential. Symbols facilitate visual comprehension and suggest comparisons 